\title{
Çocuk yoğun bakımda magnezyum düzeyi prognoz ve enfeksiyon ile ilişkili midir?
}

\author{
Fatih AYGÜN ${ }^{1}$
}

\begin{abstract}
$\ddot{\mathbf{O z}}$
Magnezyum, insan vücudunda dördüncü en çok bulunan esansiyel elementtir. Esas olarak kemik dokuda yer alan magnezyum özellikle nöroendokrin yolakların düzgün çalıșması için gereklidir. Beslenme sorunları, malnütrisyon, altta yatan kronik hastalıklar ve ilaç kullanımı gibi hazırlayıcı nedenlerden dolayı magnezyum eksikliği yoğun bakım hastalarında sık görülmektedir. Yetişkin yoğun bakım hastalarında yapılan çalışmalarda hasta prognozu ile hipomagnezeminin ilişkili olduğuna dair birçok çalışma olmasına rağmen çocuk yoğun bakım hastalarında yeterli çalışma ve kanıt bulunmamaktadır. Bu nedenle biz de bu çalışmada çocuk yoğun bakım hastalarında başvuru sırasındaki magnezyum düzeyi ile prognoz arasındaki ilişkiyi araştırmayı ve böylece $\mathrm{Mg}$ ile ilgili farkındalık oluşturmayı amaçladık. Çocuk Yoğun Bakım Ünitesi'ne Ekim 2016-Şubat 2018 tarihleri arasında yatırılan tüm hastaların verileri geriye dönük olarak toplandı. Hastalar magnezyum düzeyi $<1.8 \mathrm{mg} / \mathrm{dl}$ ve $>1.8 \mathrm{mg} / \mathrm{dl}$ olarak iki gruba ayrıld1. Gruplar arasındaki demografik ve prognostik faktörler karşılaştırıldı. Toplam 302 hastanın 50'sinde (\%16.6) magnezyum düzeyi $<1.8 \mathrm{mg} / \mathrm{dl}$ saptandı. İnotrop kullanımı, kan ürünü transfüzyonu, plazma değişimi, akut böbrek hasarı, sürekli renal replasman tedavisi, yatışta eşlik eden enfeksiyon, çocuk mortalite risk skoru (PRISM-III) ve sepsis ile magnezyum düşüklüğü arasında istatistiksel olarak anlamlı ilişki saptandı. Magnezyum düzeyi düşük olan grupta trombosit ve lenfosit sayısı anlamlı düşük, C-reaktif protein ve prokalsitonin ise anlamlı yüksek saptandı. Sonuç olarak çocuk yoğun bakımda yatan hastalarda magnezyum düşüklüğü prognozu etkileyen bir risk faktörü olarak değerlendirilmelidir.
\end{abstract}

Anahtar Kelimeler: Yoğun bakım, prognoz, magnezyum, hipomagnezemi, mortalite

\section{Is magnesium level is associated with prognosis and concommitant infection in pediatric}

\section{intensive care?}

Fatih AYGÜN ${ }^{1}$

\begin{abstract}
Magnesium is the fourth most common essential element in the whole body. Magnesium, which is mainly stored in bone tissue, is necessary for proper function of neuroendocrine pathways. Hypomagnesemia is common in patients in intensive care unit due to feeding disorders, malnutrition, secondary chronic disorders and drug use. Although there are various studies in adults regarding the effect of hypomagnesemia on the prognosis of patients in intensive care unit, there is not enough study and proof in children. Therefore, in this study we aimed to evaluate the impact of initial serum magnesium levels on the outcome of patients in pediatric intensive care unit and raise awareness. The records of patients, who were hospitalized in pediatric intensive care unit between October 2016 and February 2018, were investigated retrospectively. According to serum magnesium levels, patients were divided into two groups, as magnesium levels $<1.8 \mathrm{mg} / \mathrm{dl}$ and $>1.8 \mathrm{mg} / \mathrm{dl}$. The demographic findings and the prognostic factors were compared between two groups. Totally 302 patients' records were evaluated. Totally 50 patients $(16.6 \%)$ had magnesium levels $<1.8 \mathrm{mg} / \mathrm{dl}$. There was a statistically significant relationship between hypomagnesemia and inotropic drug use, blood component transfusion, plasma exchange, acute kidney injury, continuous renal replacement therapy, concomitant infection at admission, PRISM-III score and sepsis. The platelet and lymphocyte numbers were significantly low and C-reactive protein and procalcitonin levels were significantly high in the group having hypomagnesemia. In conclusion, hypomagnesemia should be considered as a risk factor in prognosis of patients in pediatric intensive care unit.
\end{abstract}

Article Info

Received:10.07.2018

Accepted:25.09.2018

Online Published:31.03.2019

DOI: $10.26453 /$ otjhs.442454

Corresponding Author Fatih AYGÜN

Keywords: Erysipelothrix rhusiopathiae, zoonoses, occupational disease, soft tissue disorder, osteomyelitis

\footnotetext{
${ }^{1}$ İstanbul Üniversitesi-Cerrahpaşa, Cerrahpaşa Tıp Fakültesi, Çocuk Yoğun Bakım Bilim Dalı
} 


\section{GíRiş}

Magnezyum (Mg), 300'den fazla enzimatik reaksiyonda yer alan yaşam için gerekli esansiyel bir element ve katyondur., ${ }^{1,2}$ Yoğun bakım hastalarında beslenme sorunları (paranteral beslenme gibi), altta yatan kronik hastalık ve malnütrisyon, kullanılan ilaçlar gibi durumların da katkısıyla \% 20 ila $\% 65^{\prime}$ oranında $\mathrm{Mg}$ eksikliği bildirilmiştir. ${ }^{3}$ Kalp ritim bozuklukları, pulmoner hipertansiyon, astım, diyabet ve böbrek hastalıklarının tedavisinde $\mathrm{Mg}$ kullanılır. ${ }^{4,5}$ Ayrıca magnezyumu düşük olan çocuklarda ağır metal toksisitesine eğilim artar ve sonuçta öğrenme bozuklukları gelişir. ${ }^{5}$ Fakat çocuk yoğun bakım (ÇYB) hastalarındaki eksikliği ile ilgili çok az bilgi bulunmaktadır. Bu kadar önemli bir elektrolit olmasına rağmen biz hekimler tarafindan yeterince

önemsenmemektedir. Bu nedenle bazı çalışmalar Mg'u "unutulmuş elektrolit" olarak tanımlamaktadır. ${ }^{6,7} \mathrm{Bu}$ çalışmada ÇYB hastalarında başvuru sırasındaki Mg düzeyi ile prognoz arasındaki ilişkinin incelenmesi ve böylece Mg ile ilgili farkındalık oluşturulması amaçlanmıştır.

\section{MATERYAL VE METOT}

Sağlık Bilimleri Üniversitesi, Okmeydanı Eğitim ve Araştırma Hastanesi (EAH) ÇYB Ünitesi'ne Ekim 2016-Şubat 2018 tarihleri arasında yatırılan tüm hastaların verileri geriye dönük olarak hasta dosyaları ve elektronik kayıt sistemleri incelenerek topland. Çalışma için
Sağlık Bilimleri Üniversitesi Okmeydanı Eğitim ve Araştırma Hastanesi Etik Kurulundan 05.06.2018 tarihli, 924 say1lı karar ile onam alınd1.

Ameliyat sonrası takip için yatırılan hastalar, 24 saatten kısa yatışı olan ve daha önce bilenen malnütrisyonu olan hastalar ile ilk gün tam kan sayımı, C-reaktif protein (CRP), prokalsitonin ve $\mathrm{Mg}$ düzeyinden biri veya birkaçı bakılmayan hastalar çalışma dışı bırakıldı.

Çalışmaya alınan tüm hastaların demografik bilgileri ve yatışı sonrası ilk laboratuvar değerleri kaydedildi. Hipomagnezemi alt sınırı laboratuvarımızın alt sınırı olan 1,8mg/dl değeri kabul edildi. Hastalar magnezyum düzeyi $<1,8 \mathrm{mg} / \mathrm{dl}$ ve $>1,8 \mathrm{mg} / \mathrm{dl}$ olarak iki gruba ayrıld . Gruplar arasındaki cinsiyet, yaş, invaziv mekanik ventilatör (IMV) ve non invaziv mekanik ventilasyon (NIV) kullanımı, inotrop ilaç kullanımı, yoğun bakım yatışı sırasında akut böbrek hasarı $(\mathrm{ABH})$ gelişmesi, sürekli renal replasman tedavisi (SRRT), yatış süresi, enfeksiyon durumları, pediatrik mortalite risk skoru (PRISM-III) ve mortalite ile ilişkileri değerlendirildi. Ayrıca magnezyum düzeyi ile risk faktörlerinin odds oranlarına da bakıldı. İstatistiksel analizde İstanbul Üniversitesi resmi web sitesinden indirilen (yalis.istanbul.edu.tr) SPSS 21 (IBM Company) paket programı kullanıldı. Çalışmadan elde sayısal veriler ortalama \pm standart sapma, kategorik veriler ise sıklık (n) ve yüzde (\%) ile belirtildi. İki grup arasındaki farkl1lıkların istatistiksel 
anlamlılığında ANOVA analizi kullanıldı. İki nominal değişken arasındaki ilişkinin değerlendirilmesinde ve odds oranı için ChiSquare Analizi kullanıldı. Elde edilen sonuçlarda P (Probability;Olasılık) değeri 0,05'in altında bulunduğunda istatistiksel olarak anlamlı kabul edildi.

\section{BULGULAR}

Toplamda 302 hasta çalışmaya alındı. Hastaların demografik özellikleri Tablo 1'de görülmektedir. Hastaların 158'i (\%52,3) erkek, 144'u (\%47,7) kızdı. Yaş dağılımları 1 ay ile 17 yaş arasında olup ortalama hasta yaşı $3,74 \pm 4,79$ yıld1. Hastaların yoğun bakıma yatış tanılarına bakıldığında en sık $111(\% 36,8)$ hasta ile solunum yolu hastalıkları olup diğer tanılar sırasıyla sepsis, nörolojik hastalık ve intoksikasyonlardı. ÇYB'da ortalama yatış süresi $8,20 \pm 11,69$ gündü. Hastaların 91'inde $(\% 30,1)$ IMV kullanılırken $148(\% 49,0)$ hastada ise NIV uygulandı. Altmış dokuz $(\% 22,8)$ hastada yoğun bakımda yatışı sırasında ABH gelişti ve bu hastaların $26(\% 8,6)$ 'sına SRRT yapıldı. Yetmiş iki $(\% 22,1)$ hastada inotrop ilaç kullanıldı. Hastaların 11'i $(\% 3,6)$ öldü.

Toplam $50 \quad(\% 16,6)$ hastada $\mathrm{Mg}$ düzeyi $<1,8 \mathrm{mg} / \mathrm{dl}$ saptand1. Magnezyum düzeyi açısından cinsiyet fark1 saptanmadi. Hipomagnezemisi olan grupta yaş ortalaması $5,37 \pm 5,33$ yıl olup magnezyum düzeyi normal hastalardan anlamlı düzeyde yüksekti $(\mathrm{p}=0,008)$. İnotrop kullanımı, kan ürünü transfüzyonu, plazma değişimi, ABH, SRRT, yatışta eşlik eden enfeksiyon, PRISM-III skoru ve sepsis ile hipomagnezemi arasında istatistiksel olarak anlamlı ilişki saptandı. IMV, NIV, yoğun bakım yatış süresi, IMV'e bağlı kalma süresi, NIV'e bağlı kalma süresi ve ölüm ile magnezyum düzeyi arasında istatistiksel anlamlı ilişki yoktu (Tablo 2).

Hastaların başvuru sırasında alınan laboratuvar değerlerine bakıldığında $\mathrm{Mg}$ düzeyi düşük olan grupta trombosit ve lenfosit sayısı anlamlı düşük, CRP ve prokalsitonin ise anlamlı yüksek saptand1 (Tablo 2).

Magnezyum düşüklüğü ile prognostik faktörler arasındaki ilişki ve odds oranlarına bakıldığında en yüksek oran SRRT ile olup daha sonra plazma değişimi, $\mathrm{ABH}$ ve inotrop ilaç kullanımı olarak saptand1. Sirasıyla odds oranları 7,75, 5,44, 4,71 ve 2,06 idi (Tablo 3).

\section{TARTIŞMA VE SONUÇ}

Magnezyum birçok enzimatik yolağın düzgün çalışmasında gerekli önemli bir elementtir. Hücre içi kalsiyumu kontrol eden enzimleri düzenleyerek, önemli hastalıkların patofizyolojisinde yer alan düz kas vazokonstriksiyonunu etkiler. Yoğun bakım hastalarında beslenme sorunları ve idrar ile $\mathrm{Mg}$ kayıpları nedeniyle hipomagnezemi sık karşılaşılan bir elektrolit bozukluğudur. $\mathrm{Mg}$ eksikliği esas olarak gastrointestinal sistem ve idrar kayıplarından kaynaklanır. Yetersiz beslenme de $\mathrm{Mg}$ eksikliğini hızlandırmaktadır. 
Magnezyum düzeyindeki değişiklikler neredeyse tüm organları etkilemekte ve hipomagnezemi sonucu ventriküler aritmi, koroner arter daralması ve ani ölüm gibi ciddi sonuçlar gelişebilmektedir.

Yetişkin hastalarda $\mathrm{Mg}$ ile ilgili çok sayıda çalışma yapılmış ve $\mathrm{Mg}$ eksikliği artmış mortalite ile ilişkilendirilmiştir. ${ }^{3,7,8}$ Limaye ve ark.'nın 100 yetişkin yoğun bakım hastası üzerinde yaptığı ileriye dönük gözlemsel çalışmada, yoğun bakım ünitesine başvuruda hastaların \%52'sinde hipomagnezemi, \%41'inde normal serum $\mathrm{Mg}$ düzeyi ve $\% 7$ 'sinde ise hipermagnezemi saptanmıştır. Aynı çalışmada hipomagnezemi saptanan hastalarda daha fazla mekanik ventilatör ihtiyacı, daha uzun mekanik ventilatöre bağlı kalma süresi, artmış sepsis insidansı ve artmış mortalite bildirilmiștir. ${ }^{8}$ Çocuk yoğun bakım hastalarında yapılan bir çalışma da ise tam tersi magnezyum düzeyi normal olanlarda mortalite daha yüksek bulunmuştur. $^{10} \quad$ Çalışmamızda ise hipomagnezemi sıklığg \%16.6 olarak bulundu. Hipomagnezemik grupta mekanik ventilatör kullanımı ile süresi ve mortalite oranı daha fazla bulunmasına rağmen gruplar arasında istatistiksel olarak anlamlı farklılık saptanmadı. Hipomagnezemi ve $\mathrm{Mg}$ eksikliği terimleri sıklıkla birbirinin yerine kullanılır. Fakat toplam vücut Mg'u eksik iken serum $\mathrm{Mg}$ düzeyi normal olabilir veya vücutta eksiklik olmadan ciddi hipomagnezemi olabilir. Bunun nedeni ise Mg'un çoğunlukla hücre içinde depolanması ve serum seviyesi ile iyi korele olmamasıdır. ${ }^{2,9}$ Sonuç olarak, serum ölçümlerinin tüm vücut $\mathrm{Mg}$ düzeyini tam olarak doğru gösterememesine bağlı olarak mortalite ve prognoz ile ilgili yapılan çalışmalarda farklılıklar saptanmış olabilir.

Sepsis tanılı hastalarda hipomagnezemi yaygındır. Hipomagnezeminin sepsis riskini ve mortaliteyi artırabileceği, bu nedenle sepsisi olan yoğun bakım hastalarının daha yakın izlenmesi gerektiği bildirilmiştir. ${ }^{11}$ Bizim çalışmamızda da en sık ikinci yatıș nedeni olan sepsisli hastalarda literatürle uyumlu olarak hipomagnezemi sıklığı anlamlı yüksek bulundu ( $\mathrm{p}=0.049)$. Ayrıca $\mathrm{Mg}$ düşük olan grupta ölen 3 hastanın da yatış tanısı sepsis idi. Magnezyumu düşük olan grupta inotrop ilaç ihtiyacı da artmıştı. Bunun nedeni olarak Mg eksikliği olan grupta daha fazla sepsis tanılı hasta olması ve böylece inotrop ihtiyacının daha fazla olması diye düşünmekteyiz.

ÇYB'da mortalite ve hastalık şiddetini belirlemek için hastaların laboratuvar ve klinik bulgularına göre PRISM gibi birçok sınıflandırma yöntemleri geliştirilmiştir. ${ }^{12}$ Literatüre bakıldığında yetişkin yoğun bakım hastalarında $\mathrm{Mg}$ düşüklüğü ile skorlama yöntemleri arasında anlamlı ilişki olduğu gösterilmiştir. ${ }^{13,14}$ ÇYB hastaları ile ilgili çalışma bulunmamaktadır. Bizim çalışmamızda da literatürle uyumlu olarak Mg'u düşük olan grupta PRISM-III skoru anlamlı yüksek saptandı.

Plazma Mg konsantrasyonu dar limitler içinde korunur. Böbrek, bu dengenin sağlanmasından sorumlu en önemli organdır. Yetişkin bir insanda 
her gün yaklaşı 2.4 gram $\mathrm{Mg}$ böbrekte filtrelenir ve $\% 5$ 'i idrarla atılır. ${ }^{15}$ Böbrekteki $\mathrm{Mg}$ emilim bölgeleri proksimal tübül, Henle kulbunun çıkan bölümü ve distal tübüldür. Esas etkili bölge Henle kulbu bölgesidir. ${ }^{16,17} \mathrm{Bu}$ emilim bölgelerini etkileyecek patolojiler $\mathrm{Mg}$ düşüklügünün esas nedenini oluşturmaktadır. ${ }^{16}$ Alves ve ark.'nın 232 hastada yapmış oldukları çalışmada hipomagnezemi renal fonksiyonun düzelmemesi için bağımsız risk faktörü olarak gösterilmiştir. ${ }^{18}$ Çalışmamızda da böbrek fonksiyonları ile hipomagnezemi arasında istatistiksel olarak anlamlı ilişki vardı. Mg'u düşük grupta $\mathrm{ABH}$ ve SRRT sıklığı anlamlı olarak yüksek saptand1.

Mg düşüklüğünün inflamasyon ile ilişkili olduğu daha önce literatürde bildirilmiştir. Özellikle Mg ve CRP arasında ters ilişki olduğunu gösteren çalışmalar vardır. Mg eksikliğinin CRP üretimini farklı mekanizmalar ile artırabileceği hayvan deneyleri ve insan çalışmalarında bildirilmiştir. 1,19 Hayvan araştırmalarında, şiddetli $\mathrm{Mg}$ eksikliğinin, makrofajlar ve lökositlerin aktivasyonu, serbest radikallerin aşırı üretimi, oksidatif stres ve inflamatuar sitokinlerin salınımı dahil olmak üzere, inflamasyona yol açtığ1 gösterilmiştir. Bunun sonucunda önemli bir inflamasyon belirteci olan ve çocuk hastalarda özellikle sık kullanılan CRP düzeyi artmaktadır. ${ }^{1}$ Meksika'da 488 adölesan üzerinde yapılan bir çalışmada $\mathrm{Mg}$ düşüklüğü ile $\mathrm{CRP}$ arasında anlamlı ilişkili olduğu saptanmıştır. ${ }^{20}$ Çalışmamızda da literatürle uyumlu olarak başvuru sırasında Mg'u düşük grupta CRP istatistiksel anlamlı olarak yüksek bulunmuştur. Ayrıca Mg düşük grubun \%76'sında yoğun bakıma yatışı sırasında enfeksiyon eşlik ediyordu.

CRP gibi önemli bir akut faz reaktanı olan prokalsitonin ile $\mathrm{Mg}$ arasındaki ilişki ÇYB hastalarında daha önce incelenmemiștir. Çalışmamızda $\mathrm{Mg}$ düşük grupta prokalsitonin anlamlı yüksek saptandı. Aynı şekilde serum Mg düzeyi ile lökosit, lenfosit ve trombosit sayısı arasındaki ilişki de ÇYB hastalarında daha önce hiç bakılmamıştır. Çalışmamızda başvuru sırasında bakılan $\mathrm{Mg}$ düzeyi düşük grupta lenfosit ve trombosit sayısı istatistiksel olarak anlamlı düşük bulundu.

Çalışmamızın bazı eksiklikleri ve kısıtlamaları bulunmaktadır. Retrospektif, tek merkezli olması ve hastaların $\mathrm{Mg}$ düzeylerinin yatışları boyunca da takip edilmemesi eksik yönleridir. Öte yandan, ÇYB hastalarında Mg eksikliğinin önemi ile ilgili yeterli çalışmanın yapılmamış olması ve hasta sayımızın fazla oluşu çalışmamızı değerli kılmaktadır. Bu kapsamda daha fazla hasta sayısı içeren prospektif ve çok merkezli çalışmalara ihtiyaç vardır. Yapılacak yeni çalışmalar ile ÇYB'da Mg eksikliğinin sıklığı ve önemi de belirlenmiş olacaktır.

Sonuç olarak ÇYB'a yatan hastalarda $\mathrm{Mg}$ düşüklügü prognozu etkileyen bir risk faktörü olarak değerlendirilmeli ve enfeksiyon ile birlikte olabileceği akılda tutularak bu hastalar yakın izlenmelidir. 


\section{KAYNAKLAR}

1. Mazur A, Maier JA, Rock E, Gueux E, Nowacki W, Rayssiguier Y. Magnesium and the inflammatory response: potential physiopathological implications. Arch Biochem Biophys. 2007;458(1):48-56.

2. Swaminathan R. Magnesium Metabolism and its Disorders. Clin Biochem Rev. 2003;24(2):47-66.

3. Zafar MS, Wani JI, Karim R, Mir MM, Koul PA. Significance of serum magnesium levels in critically ill-patients. Int J Appl Basic Med Res. 2014;4(1):34-37.

4. Demirtük Z., Esen F. The Unknown Miracle of the Forgotten Element: "Magnesium and Immunity" J Turk Soc Intens Care 2017;15:4752

5. Whang R. Magnesium deficiency: Pathogenesis, prevelance, and clinical implications. Am J Med 1987;82:24-9.

6. Gonzalez W, Altieri PI, Alvarado S, et al. Magnesium: the forgotten electrolyte. Bol Asoc Med P R. 2013;105(3):17-20.

7. Elin RJ. Magnesium: the fifth but forgotten electrolyte. Am J Clin Pathol. 1994;102(5):616622.

8. Limaye CS, Londhey VA, Nadkart MY, Borges NE. Hypomagnesemia in critically ill medical patients. J Assoc Physicians India. 2011;59(1):19-22.
9. Tong GM, Rude RK. Magnesium deficiency in critical illness. J Intensive Care Med. 2005;20(1):3-17.

10. Haque A, Saleem AF. On admission hypomagnesemia in critically ill children: Risk factors and outcome. Indian $\mathbf{J}$ Pediatr. 2009;76(12):1227-30.

11. Velissaris D, Karamouzos V, Pierrakos C, Aretha D, Karanikolas M. Hypomagnesemia in Critically Ill Sepsis Patients J Clin Med Res. 2015;7(12):911-918.

12. Gonçalves JP, Severo M, Rocha C, et al. Performance of PRISM III and PELOD-2 scores in a pediatric intensive care unit. Eur $\mathbf{J}$ Pediatr 2015;174:1305-10.

13. Safavi M, Honarmand A. Admission hypomagnesemia-impact on mortality or morbidity in critically ill patients. Middle East J Anaesthesiol. 2007;19(3):645-660.

14. Rubeiz GJ, Thill-Baharozian M, Hardie D, Carlson RW. Association of hypomagnesemia and mortality in acutely ill medical patients. Crit Care Med. 1993;21(2):203-209.

15. Sutton RA, Domrongkitchaiporn S. Abnormal renal magnesium handling. Miner Electrolyte Metab. 1993;19(4-5):232-240.

16. Cole DE, Quamme GA. Inherited disorders of renal magnesium handling. J Am Soc Nephrol. 2000;11(10):1937-1947. 
17. Quamme GA, de Rouffignac C. Epithelial magnesium transport and regulation by the kidney. Front Biosci. 2000;5:694-711.

18. Alves SC, Tomasi CD, Constantino L, et al. Hypomagnesemia as a risk factor for the nonrecovery of the renal function in critically ill patients with acute kidney injury. Nephrol Dial Transplant. 2013;28(4):910-916.
19. Dibaba DT, Xun P, He K. Dietary Magnesium Intake is Inversely Associated with Serum Creactive Protein Levels: Meta-analysis and Systematic Review. Eur J Clin Nutr. 2015;69(3):410.

20. Rodríguez-Morán M, Guerrero-Romero F. Serum magnesium and C-reactive protein levels. Arch Dis Child. 2008;93(8):676-80. 
Tablo 1. Çalışmaya alınan tüm hastaların demografik özellikleri.

\begin{tabular}{|c|c|}
\hline & $\mathrm{n}(\%) /$ Mean \pm S.D. \\
\hline Erkek & $158(\% 52,3)$ \\
\hline Cinsiyet & $144(\% 47,7)$ \\
\hline Hastaların Yaş Dağılımı (yıl) & $3,74 \pm 4,79$ y1l \\
\hline Akut Böbrek Hasarı & $69(\% 22,8)$ \\
\hline İnotrop İlaç Kullanımı & $72(\% 23,8)$ \\
\hline Nefrotoksik İlaç Kullanımı & $68(\% 27,2)$ \\
\hline Sürekli Renal Replasman Tedavisi & $26(\% 8,6)$ \\
\hline Mekanik Ventilatör Kullanımı & $91(\% 30,1)$ \\
\hline Yoğun bakım yatış süresi (gün) & $8,20 \pm 11,69$ \\
\hline Non-invazif mekanik ventilasyon & $148(\% 49,0)$ \\
\hline PRISM-III skoru & $11,66 \pm 10,15$ \\
\hline Plazma değişimi & $8(\% 2,6)$ \\
\hline Magnezyum düzeyi <1,8mg/dl & $50(\% 16,6)$ \\
\hline Ölüm & $11(\% 3,6)$ \\
\hline \multicolumn{2}{|l|}{ Yoğun Bakım Yatış Nedeni } \\
\hline Solunum Yolu Hastalığ & $111(\% 36,8)$ \\
\hline Nörolojik Hastalık & $45(\% 14,9)$ \\
\hline Sepsis & $47(\% 15,6)$ \\
\hline İntoksikasyon & $34(\% 11,3)$ \\
\hline Kardiyovaskuler Hastalık & $19(\% 6,3)$ \\
\hline Hematolojik/Onkolojik & $13(\% 4,3)$ \\
\hline Travma/Cerrahi & $11(\% 3,6)$ \\
\hline Diğer & $22(\% 7,3)$ \\
\hline
\end{tabular}

PRISM: Pediatric Risk of Mortality (Pediatrik Mortalite Riski Skorlamas1 ) 
Tablo 2. Magnezyum düzeyine göre çocuk yoğun bakım prognozunu etkileyen risk faktörlerinin ve laboratuvar sonuçlarının karşılaştırılması.

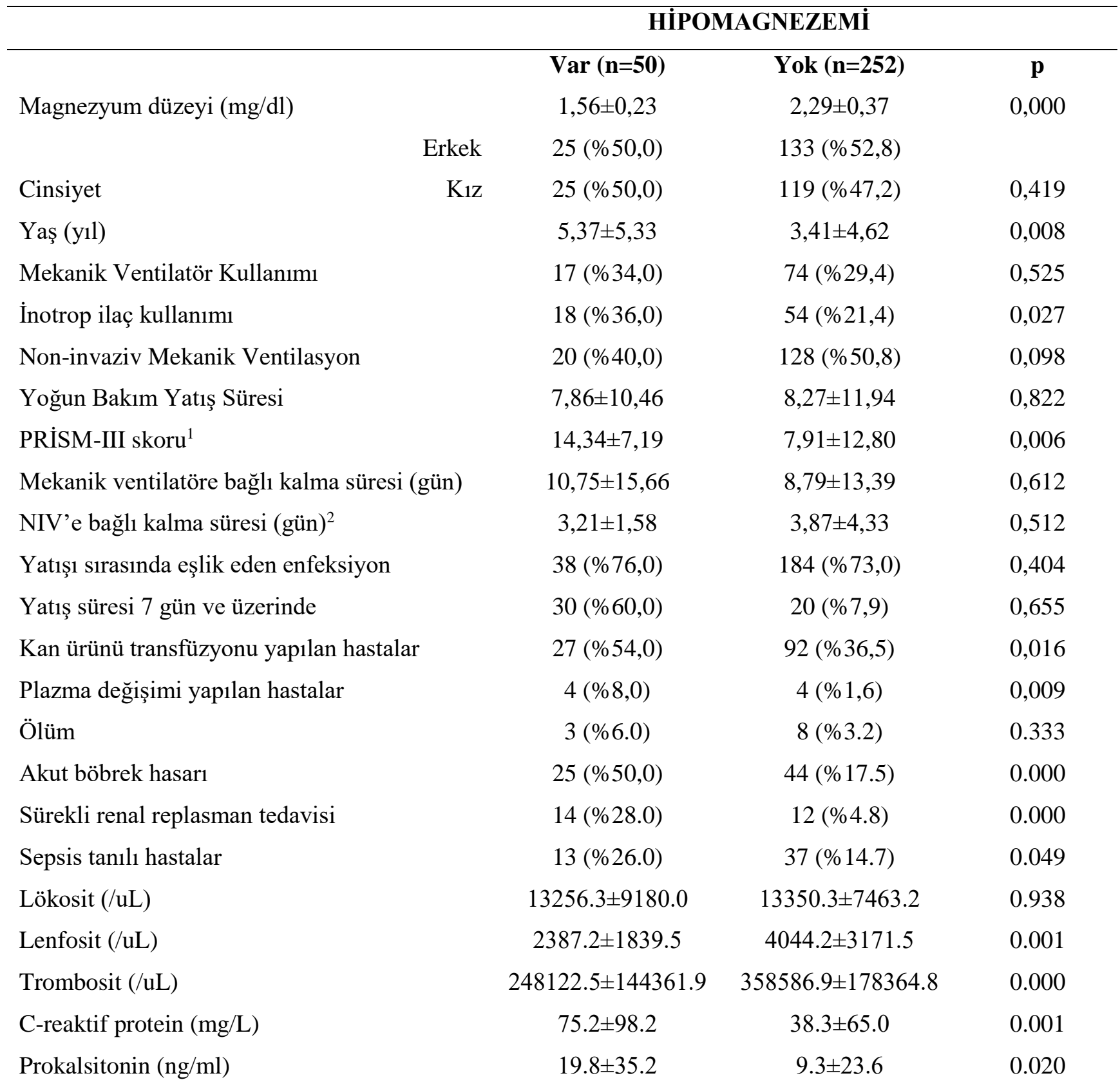

PRISM: Pediatric Risk of Mortality (Pediatrik Mortalite Riski Skorlamasl ); NIV: Non-invaziv Mekanik Ventilasyon 
Tablo 3. Magnezyum düşüklüğü ile risk faktörlerinin karşılaştırılması.

\begin{tabular}{lcc}
\hline \multicolumn{1}{c}{ RİSK } & OO & \%95 GA \\
\hline Eşlik Eden Enfeksiyon & 1,17 & $0,58-2,37$ \\
Mekanik Ventilatör Kullanımı & 1,23 & $0,65-2,35$ \\
Non-İnvazif Mekanik Ventilatör Kullanımı & 0,64 & $0,34-1,18$ \\
İnotrop ilaç kullanımı & 2,06 & $1,08-3,96$ \\
Ölüm & 1,94 & $0,49-7,58$ \\
Plazma değişimi & 5,44 & $1,31-22,57$ \\
Kan ürünü transfüzyonu & 2,04 & $1,11-3,77$ \\
Akut böbrek hasarı & 4,71 & $2,47-8,95$ \\
Sürekli renal replasman tedavisi & 7,75 & $3,32-18,07$ \\
\hline
\end{tabular}

OO: odds oranı; GA: güven aralığ 